\title{
Present Status of Field Crop Farming Mechanization in Liaoning - a Survey of 1380 Households*
}

\author{
Shen Ping, Dai Pengjun* \\ College of Economics and Management, Shenyang Agricultural University, Liaoning 110866, China \\ moonwine@163.com,*daipj53@sina.com
}

\begin{abstract}
To find out the present status of agricultural mechanization in field crop producing, a survey was conducted in Liaoning in 2013. Based on data of 1380 rural households engaged in small-scale( under $100 \mathrm{mu}$ ) field crop farming which is prevailing in Liaoning, this study finds that regional disparity exist in household machinery ownership, agricultural mechanization level, cost of machinery service and service provider structure.
\end{abstract}

Index terms - small-scale farming, field crop, agricultural modernization of China

\section{Introduction}

Being one of the main crop-producing provinces in China, Liaoning produced crops totaling 21.96 billion kilograms in 2013 and ranked 12th in the country [1]. Agricultural mechanization in Liaoning crop producing is an important index of its agricultural modernization level. No 1 Document issued by the central government of China at the beginning of each year covers the main goals for the year.In the 2014 No.1 Document just issued, the central government called for "speeding up promotion of mechanization of complete procedure of field crops". Liaoning's main field crops are corn and paddy rice. Information of the present condition of Liaoning field crop farming mechanization is essential to achieving that goal of No 1 Document.

Although the central government called for "family farm" to rise as the main management body in agricultural production, most rural regions still witness vast amount of households with small scale farming. Literature about Liaoning agricultural mechanization is rich, but still lacks substantial data at county level and household information. This paper aims to provide some basic information about employment of farm machinery for prevailing small-scale field crop production( paddy rice and corn) by Liaoning farmers, based on a survey conducted through July to August 2013, by research team members of New Countryside Development Academy of Shenyang Agricultural University.

\section{Data and Method}

Liaoning is situated in the northeast of China. The east of Liaoning is mountainous, and the west is semiarid hilly area; vast areas in the north, south and central part of Liaoning belongs to Liao River plain and are the main cropping area for paddy rice, corn, bean, sorghum, wheat

Liaoning province boasts of 44 counties, among which
23 counties were selected covering all regions of Liaoning: Lingyuan, Suizhong and Jianchang County in the west; Beipiao, Zhangwu, Fumeng, Dawa, Beizhen, Linghai, Tai'an, Panshan, Haicheng and Liaoyang in the center of Liaoning; Wafangdian, Zhuanghe, Gaizhou in the south of Liaoning; Fengcheng, Kuandian ,Huanren in the east; Qingyuan, Tieling, Faku, Changtu in the north of Liaoning province.

The townships in each county were classified into 3 groups with reference to their economic development information provided by local county officials, and from each group one township was selected as our study sample. So we have 69 sample townships. Then three villages were selected in each sample township, with reference to their general social and economic condition given by township cadres, so we have 207 villages as samples.

Although some rural regions are featured with a certain field crop production, not every household in the village would take it as main business. There is no ready list of field crop farming households at village level. In each village 10 rural households were selected from through interval sampling method, and in this way we reached 2070 rural households in Liaoning province. Half of Liaoning province's counties and typical villages of different social economic conditions were covered in the survey.

Among 2070 questionnaires handed out to village households, 1743 questionnaires were valid. From the valid questionnaires, by types of main-income-source business for the family we sorted out 1437 households which take field crop production as one of their main business. The other 306 households are mainly fishing farmers, poultry farmers, pig farmers, silkworm farmers etc, and there are also families who have moved out of the village and live as migrant workers in the cities.

According to the literature about farming scale, rural households in northeast China could be classified into following types: prevalent "common-scale" farming households which farm land below $100 \mathrm{mu}$ ( 1 hectare equals $15 \mathrm{mu}$ ), and "big-scale" farming households, which farm 100 mu and above [2]. We find 1380 households out of 1437 are engaged with "common-scale farming household", or hereby "households of small-scale farming" in this study, i.e., these households all farm field crop under $100 \mathrm{mu}$, and 57 households can be called "big scale" farming household as

\footnotetext{
* This research was co-sponsored by Special Fund for Agro-scientific Research in the Public Interest (Grant NO. 201103001), Liaoning Philosophy and Social Science Planning Fund (Grant NO. L12DSH030) and research fund of New Countryside Development Academy of Shenyang Agricultural University
} 
they farm more than $100 \mathrm{mu}$. The data analysis in this paper will be based on 1380 questionnaires of households engaged in "small scale" farming.

\section{Results and Findings}

Present status and characteristics of agricultural mechanization in small-scale field crop production of Liaoning are as follows:

\section{A. Conditions of Farm Machinery Ownership, Machine Amount and Value}

Our survey showed that among 1380 households which farm under $100 \mathrm{mu}, 569$ households own at least one farming machine, the percentage being $41.2 \%$.

A total of 772 machines are owned by small-scale farming households, with 0.6 machines per household; for 569 households with machines, there are 1.4 machines per household on average.

Total value of agricultural machines in small-scale farming is 11764475 yuan, with 8513 yuan per household. Households in Changtu county claimed the highest value of 30291 yuan. The low machine value per household could be found with Lingyuan county, Huanren county, Beipiao county, Qingyuan county and Suizhong county (see table 1).

TABLE 1 Comparison of Ownership and Machine Value in Liaoning

\begin{tabular}{|c|c|c|c|c|}
\hline & \multicolumn{2}{|c|}{$\begin{array}{c}\text { All small-scale farming } \\
\text { households surveyed in the } \\
\text { locality }\end{array}$} & \multicolumn{2}{c|}{$\begin{array}{c}\text { Households with machine } \\
\text { ownership in the locality }\end{array}$} \\
\cline { 2 - 5 } County & $\begin{array}{c}\text { Average } \\
\text { Amount of } \\
\text { machine } \\
\text { owned per } \\
\text { household }\end{array}$ & $\begin{array}{c}\text { Average value } \\
\text { of machine } \\
\text { owned per } \\
\text { household } \\
\text { (yuan) }\end{array}$ & $\begin{array}{c}\text { Average } \\
\text { Amount of } \\
\text { Machine } \\
\text { Owned per } \\
\text { household }\end{array}$ & $\begin{array}{c}\text { Average value } \\
\text { of machine } \\
\text { owned per } \\
\text { household } \\
\text { (yuan) }\end{array}$ \\
\hline Faku & 0.8 & 15480 & 1.2 & 30574 \\
\hline Tieling & 0.5 & 5519 & 1.9 & 19663 \\
\hline Changtu & 0.6 & 30291 & 1.8 & 95720 \\
\hline Wafangdian & 0.8 & 5954 & 1.2 & 10122 \\
\hline Zhuanghe & 0.8 & 2001 & 1.6 & 8424 \\
\hline Haicheng & 0.4 & 16864 & 1.7 & 82917 \\
\hline Taian & 0.4 & 6317 & 1.4 & 19708 \\
\hline Qingyuan & 0.9 & 4170 & 1.2 & 6985 \\
\hline Huanren & 0.8 & 3738 & 1.5 & 10223 \\
\hline Fengcheng & 0.4 & 6109 & 1.3 & 20451 \\
\hline Kuandian & 0.3 & 5122 & 1.1 & 20487 \\
\hline Linghai & 0.5 & 11203 & 1.6 & 36046 \\
\hline Beizhen & 0.4 & 7972 & 1.4 & 27200 \\
\hline Gaizhou & 0.1 & 313 & 1 & 2500 \\
\hline Zhangwu & 0.1 & 1000 & 1 & 7000 \\
\hline Fumeng & 0.8 & 7660 & 1.2 & 15531 \\
\hline Liaoyang & 0.3 & 14160 & 1.4 & 56639 \\
\hline Lingyuan & 0.4 & 2488 & 1.2 & 7567 \\
\hline Beipiao & 0.5 & 4038 & 1.1 & 9460 \\
\hline Panshan & 0.4 & 5870 & 1.7 & 33750 \\
\hline Dawa & 0 & 0 & 0 & 0 \\
\hline Suizhong & 0.4 & 4313 & 1.2 & 12938 \\
\hline Jianchang & 0.3 & 8675 & 1.2 & 31545 \\
\hline
\end{tabular}

\section{B. Mechanization Level in terms of Farming Process}

Whole process mechanization in field crop farming is the goal for central government. What is the present level of mechanization in different processes then? Our study finds that, for small-scale field crop farming in Liaoning, generally speaking, machine plowing used more often than machine transplanting, and transplanting is more often than machine harvesting.

Table 2 describes cropping area concerning machine employment in different steps of process, plowing, transplanting/ sowing and harvesting. The average figure is calculated using data only from households who use machine, excluding those household that do not use machine in the corresponding process.

TABLE 2 Comparison of Mechanization Level of Farming Processes

\begin{tabular}{|c|c|c|c|c|c|c|c|c|}
\hline \multirow{2}{*}{ County } & \multicolumn{2}{|c|}{$\begin{array}{c}\text { Machine } \\
\text { plowing }\end{array}$} & \multicolumn{2}{c|}{$\begin{array}{c}\text { Machine } \\
\text { sowing } \\
\text { of corn }\end{array}$} & $\begin{array}{c}\text { Machine } \\
\text { transplanting } \\
\text { of rice }\end{array}$ & \multicolumn{2}{c|}{$\begin{array}{c}\text { Machine } \\
\text { harvesting }\end{array}$} \\
\cline { 2 - 10 } & $\begin{array}{c}\text { Crop } \\
\text { area } \\
(\mathrm{mu})\end{array}$ & $\begin{array}{c}\text { Perce } \\
\text { ntage }\end{array}$ & $\begin{array}{c}\text { Crop } \\
\text { area } \\
(\mathrm{mu})\end{array}$ & $\begin{array}{c}\text { Perce } \\
\text { ntage }\end{array}$ & $\begin{array}{c}\text { Crop } \\
\text { area } \\
(\mathrm{mu})\end{array}$ & $\begin{array}{c}\text { Percent } \\
\text { age }\end{array}$ & $\begin{array}{c}\text { Crop } \\
\text { area } \\
(\mathrm{mu})\end{array}$ & $\begin{array}{c}\text { Percent } \\
\text { age }\end{array}$ \\
\hline Faku & 16.4 & 86.2 & 17.2 & 89 & 0 & 0 & 19 & 15 \\
\hline Tieling & 22.9 & 93.4 & 21.8 & 87.4 & 13.1 & 16.9 & 19.8 & 65.5 \\
\hline Changtu & 21.3 & 90.8 & 20.9 & 80.9 & 0 & 0 & 20.4 & 36.4 \\
\hline Wafangdian & 15.2 & 75.6 & 16.5 & 72.7 & 0 & 0 & 44.4 & 22.4 \\
\hline Zhuanghe & 14 & 76 & 10.7 & 31.3 & 10.6 & 52.4 & 14.3 & 23.9 \\
\hline Haicheng & 22.5 & 94.8 & 26.2 & 89.4 & 2 & 16.7 & 45.2 & 49.5 \\
\hline Taian & 16.4 & 94.9 & 17.6 & 84 & 1.5 & 2.6 & 17.3 & 21.8 \\
\hline Qingyuan & 9.7 & 59.9 & 4.5 & 9.8 & 4.8 & 16.5 & 10.3 & 6.2 \\
\hline Huanren & 10.6 & 41.8 & 14.8 & 18.5 & 17.7 & 60.9 & 5.7 & 4.5 \\
\hline Fengcheng & 34.8 & 67.4 & 119.2 & 44.1 & 2.3 & 4.6 & 44.3 & 49 \\
\hline Kuandian & 6.9 & 38.6 & 97.7 & 34.8 & 0 & 0 & 0 & 0 \\
\hline Linghai & 28.2 & 81 & 29.3 & 69.7 & 30.9 & 83.7 & 37.3 & 63 \\
\hline Beizhen & 9.2 & 85 & 9.2 & 64.6 & 0 & 0 & 10.8 & 18.5 \\
\hline Gaizhou & 2 & 100 & 2.2 & 36.7 & 0 & 0 & 0 & 0 \\
\hline Zhangwu & 7.9 & 100 & 8 & 58.2 & 0 & 0 & 0 & 0 \\
\hline Fumeng & 24.7 & 92.8 & 24.4 & 86.7 & 0 & 0 & 26.2 & 40.6 \\
\hline Liaoyang & 70.3 & 95.8 & 50.5 & 91.1 & 65.5 & 86.1 & 73.1 & 91.4 \\
\hline Lingyuan & 6.6 & 93.4 & 6.8 & 78 & 0 & 0 & 0 & 0 \\
\hline Beipiao & 10.5 & 67.7 & 9.3 & 23.6 & 0 & 0 & 0 & 0 \\
\hline Panshan & 43.4 & 97.5 & 0 & 0 & 70 & 94.4 & 150 & 33.7 \\
\hline Dawa & 11.1 & 58.7 & 0 & 0 & 10.8 & 100 & 12 & 16 \\
\hline Suizhong & 12.2 & 89.2 & 12.4 & 86.1 & 2 & 44.4 & 13.7 & 17.7 \\
\hline Jianchang & 11.6 & 89.5 & 12.7 & 65.1 & 3 & 27.3 & 22 & 4.6 \\
\hline
\end{tabular}

Note: Crop area per household (mu): crop area involved in machine plowing, sowing, transplanting, harvesting respectively.

Percentage means the percentage of machine plowing area of the household' whole crop area. 
Our study finds that, in 2012, integrated agricultural mechanization level of small-scale field crop farming in Liaoning is $66 \%$. County specific data are shown in figure 1 . As could be seen from the figure, different regions in Liaoning have a great difference in level of mechanization.

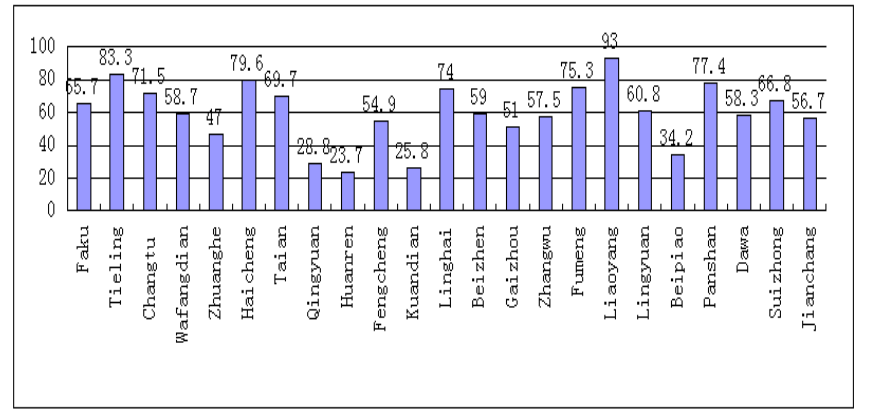

Fig. 1 Integrated agricultural mechanization level for field crop of 23 counties in Liaoning

\section{Cost of Farm Machinery Service in Small-scale Field Crop Farming}

A household with small-scale farming may pay money to get the machinery service. Information of cost for service by counties is shown in table 3 .

TABLE 3 Cost of Machine Service per mu in Liaoning (yuan/per mu)

\begin{tabular}{|c|c|c|c|c|}
\hline County & $\begin{array}{c}\text { Machine } \\
\text { plowing }\end{array}$ & $\begin{array}{c}\text { Machine } \\
\text { sowing }\end{array}$ & $\begin{array}{c}\text { Machine } \\
\text { transplanting }\end{array}$ & $\begin{array}{c}\text { Machine } \\
\text { harvest }\end{array}$ \\
\hline Faku & 30.1 & 27.26 & 0 & 77 \\
\hline Tieling & 47.17 & 48.14 & 202.5 & 118.14 \\
\hline Changtu & 42.78 & 27.87 & 0 & 98.27 \\
\hline Wafangdian & 55.56 & 47 & 0 & 73.33 \\
\hline Zhuanghe & 53.92 & 48.08 & 81.88 & 95.33 \\
\hline Haicheng & 53.33 & 32.65 & 130 & 85 \\
\hline Taian & 38.81 & 28.34 & 59 & 88.46 \\
\hline Qingyuan & 67.05 & 68 & 112.5 & 92.5 \\
\hline Huanren & 93.49 & 88.33 & 107.14 & 116.67 \\
\hline Fengcheng & 63.86 & 35 & 165 & 106.67 \\
\hline Kuandian & 108 & 100 & 0 & 0 \\
\hline Linghai & 43.64 & 30.96 & 86.56 & 105.65 \\
\hline Beizhen & 47.69 & 30.63 & 0 & 81.43 \\
\hline Gaizhou & 90.71 & 60 & 0 & 0 \\
\hline Zhangwu & 38.57 & 31.25 & 0 & 0 \\
\hline Fumeng & 33.55 & 33.24 & 0 & 67.78 \\
\hline Liaoyang & 55.35 & 38.18 & 192.14 & 130 \\
\hline Lingyuan & 57.87 & 38.04 & 0 & 0 \\
\hline Beipiao & 42.05 & 37.92 & 0 & 0 \\
\hline Panshan & 41.67 & 0 & 116 & 0 \\
\hline Dawa & 48.75 & 0 & 56.43 & 160 \\
\hline Suizhong & 48.82 & 28.93 & 0 & 65 \\
\hline Jianchang & 48.11 & 29.38 & 180 & 100 \\
\hline
\end{tabular}

Our study shows that the average cost for machine plowing per mu in Liaoning is 50.07yuan, machine sowing service ( for corn) 34.93 yuan, machine transplanting( for rice) 124.95 yuan, and machine harvest service 105.26 yuan.

\section{Structure of agricultural machinery service provider}

Our study finds that, generally in Liaoning province, machine service provided to small-scale farming composes of agricultural machinery specialty household $(72.9 \%$ in average), agricultural machinery specialty cooperatives $(2.6 \%$ in average), cross region employment of machinery (3.8\% in average), and the remaining is farmers using of their own farm machinery (20.7\% in average). County-specific information is included in table 4.

TABLE 4 Farming Machinery Service Provider Structure in Liaoning ( \%)

\begin{tabular}{|c|c|c|c|c|}
\hline county & $\begin{array}{c}\text { machinery } \\
\text { specialty } \\
\text { household }\end{array}$ & $\begin{array}{c}\text { machinery } \\
\text { specialty } \\
\text { cooperative }\end{array}$ & $\begin{array}{c}\text { cross region } \\
\text { employ-ment }\end{array}$ & $\begin{array}{c}\text { Machinery self } \\
\text { owned by } \\
\text { farmers }\end{array}$ \\
\hline Faku & 94.1 & 0 & 0 & 5.9 \\
\hline Tieling & 61.2 & 10.2 & 14.3 & 14.3 \\
\hline Changtu & 68.9 & 10.8 & 1.4 & 18.9 \\
\hline Wafangdian & 70.7 & 1.7 & 0 & 27.6 \\
\hline Zhuanghe & 74.5 & 2 & 0 & 23.5 \\
\hline Haicheng & 74.4 & 0 & 2.3 & 23.3 \\
\hline Taian & 73.5 & 0 & 2.9 & 23.6 \\
\hline Qingyuan & 92.1 & 0 & 0 & 7.9 \\
\hline Huanren & 77.1 & 0 & 2.1 & 20.8 \\
\hline Fengcheng & 37 & 11.1 & 11.1 & 40.8 \\
\hline Kuandian & 22.2 & 0 & 5.6 & 72.2 \\
\hline Linghai & 77.8 & 1.9 & 7.4 & 12.9 \\
\hline Beizhen & 80.6 & 0 & 0 & 19.4 \\
\hline Gaizhou & 100 & 0 & 0 & 0 \\
\hline Zhangwu & 100 & 0 & 0 & 0 \\
\hline Fumeng & 38.2 & 2.6 & 1.3 & 57.9 \\
\hline Liaoyang & 45.9 & 6.6 & 18 & 29.5 \\
\hline Lingyuan & 83.8 & 0 & 2.9 & 13.3 \\
\hline Beipiao & 93.2 & 0 & 0 & 6.8 \\
\hline Panshan & 57.1 & 28.6 & 0 & 14.3 \\
\hline Dawa & 85.7 & 0 & 14.3 & 0 \\
\hline Suizhong & 97.1 & 0 & 29.1 & 0 \\
\hline Jianchang & 91.9 & 0 & 2.7 & 5.4 \\
\hline
\end{tabular}

\section{Conclusions}

A. Liaoning's Integrated Level of Mechanization is Comparatively High, but Regional Disparity Exists

Liaoning witnesses variety in geography and cropping as could be seen from the county-level data.. The difference in geography and cropping also result in difference in farming mechanization. In mountainous counties like Huanren, the integrated level of mechanization is only around $20 \%$, while in Liaoyang, which is at the center of Liaoning and mainly plain area, the mechanization level is very high.Both farm 
machinery level and cost differ from county to county.

Nonetheless, Liaoning's integrated mechanization level reached $66 \%$ in 2012 , relatively higher comparing to national level of $57 \%$ [3].

\section{B. Integrated level of mechanization also differ for corn and paddy rice.}

Rice paddy mechanization level is higher than corn in Liaoning. In paddy field in Panjin county, a main paddy rice production region, services of cross region employment of machine are common, but few such services are seen for corn production.

Speeding up Mechanization in corn production is an important issue for Liaoning. In 2011, the Ministry of Agricultural of P.R.C demanded machine harvest level being at least 30\% for corn, and Liaoning's corn mechanization level is low. Machine harvest level of $43.5 \%$ counties surveyed is below 30\%, and in Mountainous Huanren county, Jianchang County and Qingyuan county, machine harvest level is $4.5 \%, 4.6 \%$ and $6.2 \%$ respectively

\section{There is difference in mechanization level among different processes of production.}

Viewed from the process of farming, Liaoning's farm machinery level is featured as: machinery plowing level higher than machine sowing/transplanting; machine sowing/transplanting level is higher than machine harvesting. This is partly due to sophistication level of machinery.

\section{Different machinery ownership Accompany Different Development Modes of Agricultural Mechanization}

Our survey shows that in the regions where higher percentage of household farm machinery ownership exist, as in Qingyuan county, Wafangdian county, Faku county, Huanren county, Zhuanghe county, Fumeng county (over 50\%), usually lower value of one machine exists too, with most small farm equipment averaging 8000 yuan per machine and land management scale in these counties relatively low, usually being 15 mu per household.

In counties with lower percentage of households farm machinery ownership, higher value per machine are often found, with worth of one machine being around 20000-50000 yuan, as in Changtu county, Haichen county, and Linghai county, Liaoyang county. Bigger scales of farming exist in these counties, averaging $33 \mathrm{mu}$ per household. In Liaoyang, the average farming scale per household is $65 \mathrm{mu}$.

\section{E. Different Farm Machinery Service Mode Accompany} Different Economic Development status

Our study shows that, in counties of lower level economic situation like Zhangwu county, Suizhong county, Faku county, Beipiao county, Qingyuan county, Jianchang county ,the main field crop is corn, and the management scale is small, and these counties have fewer machinery owned by farmers themselves, 92\% machinery service is provided by farm machinery speciality households. While in better-off counties like Wafangdian county, Zhuanghe county, Haicheng county, Tai'an county, the main crop is paddy rice, scale for land manangement is usually bigger, and a ratio of $7: 3$ for service provided by farm machinery speciality households and selfprovided machinery is recorded.

\section{Acknowledgment}

Shen Ping and Dai Pengjun wish to express their hearty appreciation for the impressive work of fellow research members of New Countryside Development Academy of Shenyang Agricultural University, in the survey conducted through July to August 2013 in Liaoning province, China.

\section{References}

[1] Official Website of Ministry of Agricultural of People's Republic of China http://www.moa.gov.cn/fwllm/qgxxlb/qg/201312/t20131204_3697576. htm

[2] Chenjie, Luodan, Household for Big-scale Cropping: one of the main force toward agricultural modernization, The Truth, 2012/03

[3] Official Website of the Central People's Government of the People's Republic of China: http://www.gov.cn/jrzg/2013-02/26/content_2340477.htm 